\title{
Exploration of Petroleum and Gas Production Engineering Teaching to International students in China
}

\author{
Wen-bin Cai, De-sheng Zhou, Xian-lin Ma, Yuan-gang Xu \\ Petroleum Engineering Academy, \\ Xi an Shiyou University \\ Xi`an, Shaanxi, 710065, China \\ peter_acai@sina.com
}

\begin{abstract}
The petroleum and gas production engineering course system is the one of most important course for petroleum engineering college. Petroleum production teaching is becoming ever more and more challenging because of increased enrollments and students' different levels of preparation. Some useful explorations were carried out to improve teaching effectiveness, course system was set up by courses arrangement in different semester following the rule of from simple course to complex course, the learning styles between different foreign students are discussed, layered teaching has been adopted in the course of petroleum production engineering, the questionnaire investigation was carried out In order to find layered teaching is reasonable, several teaching reform methods were also carried out during international students teaching, a variety of teaching methods were adopted to increase students' interaction in teaching activities, Some oil field development examples were discussed in our class to stimulate students' interest in learning, online teaching website of petroleum and gas production engineering course system were built for students learning at spare time, a variety of testing methods were adopted to reflect learning situation.
\end{abstract}

Keywords-teaching methods reform; international students in China; petroleum and gas production engineering teaching; reform in teaching method

\section{INTRODUCTION}

The number of students from all over the world studying in China is increasing rapidly in recent years, international cooperation and students exchange between different colleges and universities are also unprecedented and fruitful. The foreign students' education is an important part of international cooperation, and also is one of the important content of universities internationalization [1-3]. Xi`an Shiyou University have done some useful exploration and practice in foreign students training, petroleum and gas production engineering course has set up a teaching system to meet the needs of foreign students education. In this paper, the learning styles between different foreign students are discussed. Many useful teaching methods are used and a variety of teaching methods were adopted to increase students' interaction in teaching activities, teaching reform methods were also carried out to improve teaching effectiveness.

\section{Course System SET UP}

The petroleum and gas production engineering course system is the one of most important course of petroleum engineering majors. The composition of petroleum and gas production engineering course system was shown in Fig.1, these are there theoretic courses in petroleum and gas production course system for both Chinese and foreign students, they are petroleum production engineering, recent advances in oil and gas production engineering, and oil and gas production science and technology, there are also two practice courses, they are petroleum engineering course exercise and oil field onsit practice.

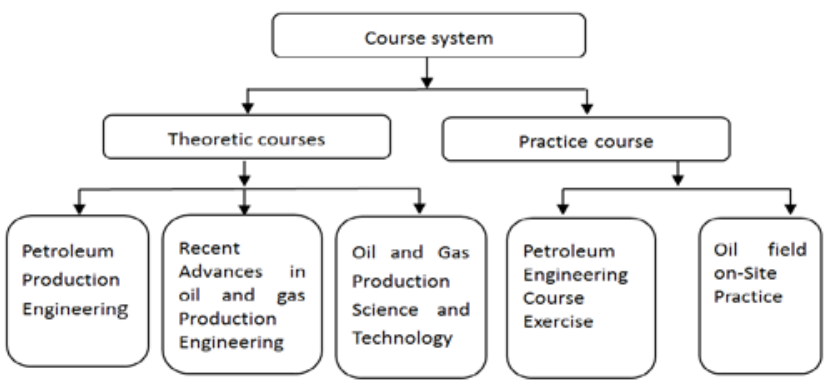

Fig. 1. The composition of petroleum and gas production engineering course system

The petroleum and gas production engineering course system set up follows the rule of from simple to complex, students take the course of petroleum production engineering at the thirst semester of the 3th year, in this course the common oil and gas science and technology are introduced, recent advances in oil and gas production engineering, and oil and gas production science and technology are optional courses which introduce new material, new technology, new science and new equipment appeared in recent 10 years.

\section{LAYERED TEACHING}

Our university foreign students are come from more than 10 countries, they mainly from South Asia (Pakistan), Africa and Central Asia. The English skill of Students from Central Asian countries is not as good as students from African 
countries, they speak slowly and the accent is more heavily. There are also many classroom disciplines and learning habits difference between foreign students and Chinese students, The foreign students are more active than Chinese students, they may stand up and ask questions directly when they were not totally understand what teacher said, but for the Chinese students, when they have some questions, first they will raise hand and then to speak after receive teacher's allowance. Because of these differences, teachers should constantly observe and understand foreign students' culture and customs before the beginning of course, in the process of teaching, we constantly communicated with students through extracurricular time, tried to understand each other's study habits and customs, and teach students in accordance with their aptitude。

Layered teaching has been adopted in the course of petroleum production engineering, the first step of layered teaching is how to divide students into different layers, and the

TABLE I. LAYERED TEACHING QUESTIONNAIRE INVESTIGATION RESULT

\begin{tabular}{|c|c|c|c|c|c|}
\hline $\begin{array}{c}\text { Investigation } \\
\text { item }\end{array}$ & Group & $\begin{array}{l}\text { Average } \\
\text { point }\end{array}$ & $\begin{array}{l}\text { Standard } \\
\text { deviation }\end{array}$ & $\begin{array}{c}\mathrm{T} \\
\text { statistic }\end{array}$ & $\begin{array}{c}\mathrm{P} \\
\text { statistic }\end{array}$ \\
\hline \multirow{2}{*}{$\begin{array}{l}\text { Layered standard is } \\
\text { reasonable }\end{array}$} & A & 4.01 & 0.77 & \multirow{2}{*}{5.36} & \multirow{2}{*}{0.00} \\
\hline & B & 2.97 & 1.16 & & \\
\hline \multirow{2}{*}{$\begin{array}{c}\text { Layered teaching } \\
\text { does not injury self } \\
\text { esteem }\end{array}$} & A & 3.72 & 1.04 & \multirow{2}{*}{5.53} & \multirow{2}{*}{0.00} \\
\hline & B & 2.73 & 1.17 & & \\
\hline \multirow{2}{*}{$\begin{array}{l}\text { Layered teaching } \\
\text { make me love the } \\
\text { course }\end{array}$} & A & 4.01 & 0.95 & \multirow{2}{*}{3.27} & \multirow{2}{*}{0.00} \\
\hline & B & 3.36 & 1.07 & & \\
\hline \multirow{2}{*}{$\begin{array}{l}\text { Layered teaching } \\
\text { Is helpful to my } \\
\text { study }\end{array}$} & A & 4.01 & 0.60 & \multirow{2}{*}{5.01} & \multirow{2}{*}{0.01} \\
\hline & B & 3.25 & 0.90 & & \\
\hline \multirow{2}{*}{$\begin{array}{l}\text { Layered teaching } \\
\text { Should be dynamic }\end{array}$} & A & 3.66 & 0.77 & \multirow{2}{*}{2.54} & \multirow{2}{*}{0.00} \\
\hline & B & 4.40 & 0.58 & & \\
\hline \multirow{2}{*}{$\begin{array}{l}\text { Layered teaching in } \\
\text { accordance with } \\
\text { student aptitude }\end{array}$} & A & 2.62 & 0.86 & \multirow{2}{*}{1.72} & \multirow{2}{*}{0.09} \\
\hline & B & 2.46 & 0.71 & & \\
\hline \multirow{2}{*}{$\begin{array}{c}\text { Layered teaching is } \\
\text { different from good } \\
\text { and no good students } \\
\text { class }\end{array}$} & A & 2.93 & 0.76 & \multirow{2}{*}{1.66} & \multirow{2}{*}{0.08} \\
\hline & B & 2.81 & 0.83 & & \\
\hline
\end{tabular}

90 students are divided into two groups $\mathrm{A}$ and $\mathrm{B}$, the questionnaire include 15 objective questions and 1 subjective question, the score adopted Likert five dimension scale from point 1 to point 5, point 1 means layered teaching is unacceptable, point 5 means layered teaching is tally acceptable, each students select a point that can reflect his real attitude about layered teaching. Point 3 is a demarcation line, students select score above 3 means they take affirmative attitude toward layered teaching [4-5].

According to the data of Table I, there is a big attitude difference of layered teaching between group $\mathrm{A}$ and $\mathrm{B}$, students were divided into group $\mathrm{A}$ and $\mathrm{B}$ based on their college entrance examination score, score of group $A$ is much higher than group B, group A think layered standard is reasonable and agree with layered teaching, however, group B is disagree with layered teaching, but they think layered teaching should be dynamic, students of group A believe that layered teaching gives more study stress, but good competition atmosphere is beneficial to the improvement of academic achievement, so following aspects should be taken into consideration in students' stratification: students' mathematics foundation, which can refer to the students' achievement in the college entrance examination, students' computer application ability and students' learning ability. We compiled specific school syllabus which include different teaching purposes, teaching contents, teaching priorities and difficulties according to students' stratification. The course contents were divided into three parts, they are teacher fully taught, teacher partly taught and students learn by themselves. During the teaching, we try to convert practice problem into mathematical model and try to improve students' ability of solve oilfield practical problems.

In order to find layered teaching is reasonable, the questionnaire investigation was carried out, 90 students and 5teachers have taken this questionnaire investigation, Table I shows the layered teaching questionnaire investigation result.

they agree with layered teaching. students of group B believe that layered teaching cannot show education equality, It has bad effect on study enthusiasm of the students, and some of the students may be backward and have no urge to make progress, so they are strongly opposed to the layered teaching, they feel that students of different levels of learning together are helpful of mutual assistance and mutual improvement, they even suggested that even students stratification cannot be carried out according to their college entrance examination, teachers should pay more attention to students' interests and respect for their personality.

\section{REFORM IN TEACHING METHOD}

Teaching method is an important factor to achieve teaching objectives and improve teaching quality, which includes two aspects: teacher education method and student learning method[6], it is the unification of teaching and learning. Our course education group often organizes seminars about teaching methods to discuss how constantly improves teaching methods and improve teaching effectiveness.

\section{A. Teaching Method}

A variety of teaching methods were adopted to increase students' interaction in teaching activities, students listening when teaching speaking is the most commonly used teaching method, but this kind of teaching method is tedious and students easy to get tired, so we change this monotonous teaching method to a combined teaching method which includes lecture, discussion and demonstration, for the basic theories or main difficult problems in textbooks, we would take discussion after student have an independent thinking, sometime we have group discussion and group debate. Through animated demonstration teaching, students can get vivid and intuitive perceptual knowledge, link the theoretical knowledge with practical things, and form a correct and profound concept.

\section{B. Oil Field Development Examples}

Some oil field development examples were discussed in our class to stimulate students' interest in learning, teaching process 
was show in Fig. 2, first teachers raised issue from problems and challenges in oil and gas development, then students think these problems and tried to find methods to solve these problems, ant end teachers would introduce some new science and technologies to stimulate students' initiative and creativity, by teaching methods reforming, students are easy to master the basic theory and knowledge, working process, technologies to improve oil production, and train the ability of analyzing and solving the practical problems.

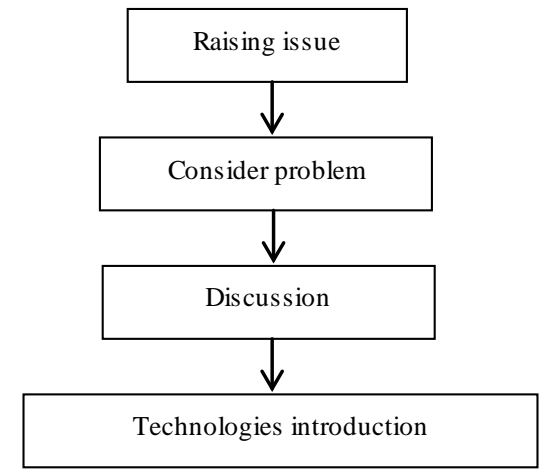

Fig. 2. Teaching process of oil field development examples

\section{Online Teaching Website}

In the class, both the multimedia and blackboard are adopted in teaching, information is more vivid by using multimedia, but for the formula derivation, blackboard writing is more clearly and more easily for students understanding. There are complete audio and video devices in our multi-media classroom. We could explain knowledge points by cartoons, power point, audio files. Internet resources were also used in class teaching, the campus network center has the Blackboard network teaching management platform, which has many useful teaching resources such as famous teacher online, excellent course website, teaching video resource base and video on demand system.

The online teaching website of petroleum and gas production engineering course system also was built, as showed in Fig. 3, online teaching website contains lesson notes, teaching courseware, video lectures, virtual experiments, synchronous tutorship, teaching staff and network answering system, which have benefited the petroleum engineering students in the universities. At present, the campus wireless network has been connected to all three campuses with 29890 information points and part of the campus area has been covered by both wired and wireless networks. The hardware system of campus network is getting better along with the developing of the campus network. The web applications in the campus network have proliferated, such as the educational management system, postgraduate management system, blackboard network teaching management platform, campus card system, office automation system, personnel management system, mail system, modern distance education platform, teacher online, English online, high-quality curriculum website, teaching video resource database and video on demand system, teacher online, high-quality curriculum website, teaching video database, video on demand system and so on.

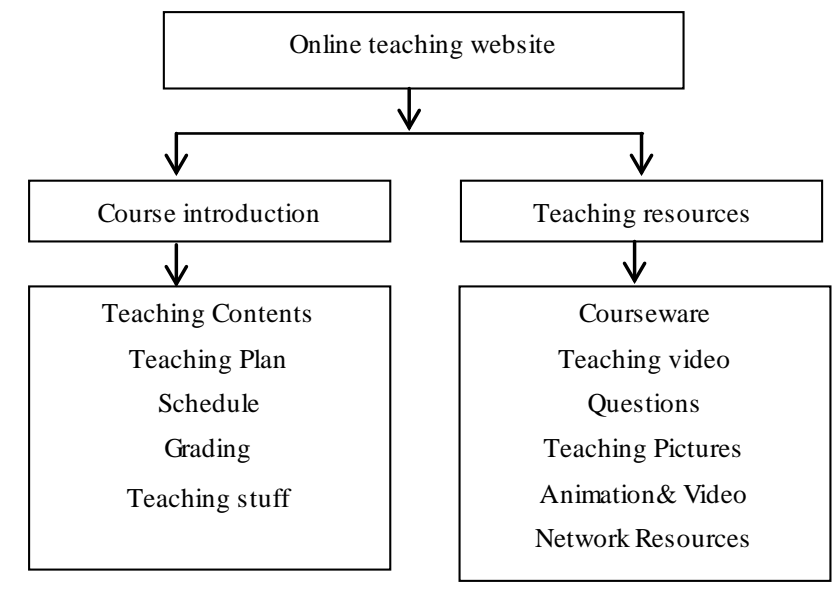

Fig. 3. The composition of course systemonline teaching website

\section{Variety of Testing Methods}

The teach staff takes a variety of testing methods including classroom quizzes, after-class projects, attendance, classroom Q\&A, final exam results, etc.. In summary, the attendance accounts for $10 \%$, the homework accounts for $20 \%$ and the final exam result accounts for $70 \%$.

\section{E. Communication between Teachers and Students}

The number of foreign students may be different for each year, students may come from different countries, and they have different knowledge base level and English pronunciation. Before each class, teachers of the course group should familiar with the subject of teaching, the number of students, knowledge base level, which country dose students come from and so on. In the classroom, teachers should check students learning effect through questions, discussions and classroom quizzes, there are 2 hours of tutoring time each week, and students can ask teachers questions that they did not understand in class teaching, while teachers and students can exchange their opinions of teaching methods, teaching content.

\section{Build a High Quality Teacher Team}

The teaching faculties are not only proficient with English but also have tremendous working experiences in oil and gas fields. Two main instructors had lived in the United States of America and worked at the well-known petroleum companies for more than 10 years, therefore, they are fluent English speakers. All of the eight members with $\mathrm{PhD}$ degrees had more than one year overseas visiting and researching experience. Two of them are 2nd class full professors, one is a member 1st batch of Shanxi's One Hundred Talent Project. All of them have profound knowledge and experiences in developing oil and gas fields.

\section{Update The Teaching Content}

The course contents are novel, and updated in time to catch the academic frontier. The purpose of petroleum and gas production engineering course system is to introduce the common and new technologies emerging in oil and gas production engineering in recent years. The update of teaching materials was shown in Table II. 
TABLE II. UPDATE OF TEACHING MATERIALS

\begin{tabular}{|l|l|}
\hline Teaching materials befor update & Teaching materials after update \\
\hline $\begin{array}{l}\text { Downhole pulsed discharge } \\
\text { increasing production technology }\end{array}$ & Natural gas production engineering \\
\hline $\begin{array}{l}\text { Artificial seismic processing } \\
\text { technique for reservoir }\end{array}$ & Advance in fracturing technology \\
\hline $\begin{array}{l}\text { Stimulation technology of } \\
\text { hydraulic oscillation }\end{array}$ & $\begin{array}{l}\text { Multi-staged fracturing technology } \\
\text { in horizontal wells }\end{array}$ \\
\hline $\begin{array}{l}\text { Downhole ultrasonic stimulation } \\
\text { treatment }\end{array}$ & $\begin{array}{l}\text { Coiled tubing production and } \\
\text { intelligent well }\end{array}$ \\
\hline $\begin{array}{l}\text { Electromagnetic waveand } \\
\text { microwave heating technology in } \\
\text { heavy oil reservoir }\end{array}$ & $\begin{array}{l}\text { Unconventional oil and gas field } \\
\text { development }\end{array}$ \\
\hline $\begin{array}{l}\text { Deep penetration perforating } \\
\text { stimulation treatment }\end{array}$ & Shale gas development \\
\hline
\end{tabular}

The textbooks newly compiled in English has included natural gas production engineering, unconventional resources development and shale gas development, presented systemically the latest science and technology in oil and gas production engineering, which resulted in broadening the students' horizon and familiarizing them with the cutting-edge technologies in natural gas and shale gas development.

\section{SUMMARY}

The petroleum and gas production engineering course system is an important course for international students majoring in Petroleum Engineering. The course contents are novel, and updated in time to catch the academic frontier. It presented systemically the latest science and technology in oil and gas production engineering, which resulted in broadening the students' horizon and familiarizing them with the cuttingedge technologies in natural gas and shale gas development. Teaching resources are complete and classroom teaching is combined with online teaching. The course has a complete set of teaching resources, including teaching syllabus, plans, textbook, multimedia courseware and questions, etc. Also there is a corresponding course website which contains lesson plans, teaching courseware, teaching videos, synchronous tutoring, and online Q \& A, which facilitate the students in their spare time or distance learning.

\section{REFERENCES}

[1] QIANG Bai-fa, An exploration of teaching chinese culture in english to international students in china, Journal of NingBo University(Educational Scince Education), vol 13, No.5, pp. 101-104, Sep. 2017 (In Chinese)

[2] Baidu. http://baike.baidu.com/view/1486108.htm

[3] PEI Xi-shan, Investigation and analysis on status of ranking teaching, Journal of ShanXi Finance and Economics University (higher education edition) Vol.11, No.2, pp59-62, Jun.,2008 . (In Chinese)

[4] LI Chun-xia, YANG Shu-guo, Explorations of and practice in layered teaching of higher mathematics, Education and Modernization, No.3, pp 30-36, Sep. 2007 (In Chinese)

[5] XU Xiao-Hui, Chun Bi, An approach to the reform of "Oil Production Engineering" course in the context of professional accreditation, Eucation Teaching Forum, No.31, pp111-112, Aug. 2017 (In Chinese)

[6] Liu,R.Q., Dai,M.C. On college english teaching reform[J]. Teaching English in China, 2004(4):3- 8. 